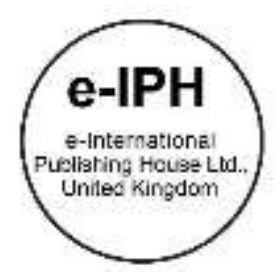

\title{
An Assessment of Land Use Planning Activities through Development Plans in Urban Housing
}

\author{
Hamizah Yakob, Yusfida Ayu Abdullah @ Mohd Zain \\ Centre of Studies for Town and Regional Planning, Faculty of Architecture, Planning and Surveying, Universiti Teknologi MARA, \\ Kampus Cawangan Selangor,42300, Bandar Puncak Alam, Malaysia \\ hamizah1204@gmail.com, ayunazeri@gmail.com \\ Tel: +60122221768
}

\begin{abstract}
Land use planning is a contributing factor in achieving better housing development in urban areas. However, the ineffectiveness during the preparation of development plans and its implementation through development control has given the impact on housing development. This paper presents a study on the effectiveness of housing planning and control activities. The best approaches to assisting its effectiveness among decision-makers and implementers in housing development were revealed. Thus, the study employs a qualitative method through in-depth interviews conducted among town planners. The study discovered the most important aspects are the availability of data in improving housing planning and control.
\end{abstract}

Keywords: Land Use Planning; Housing Planning; Planning Control; Development Plan

eISSN: 2398-4287@ 2021. The Authors. Published for AMER ABRA cE-Bs by e-International Publishing House, Ltd., UK. This is an open access article under the CC BYNC-ND license (http://creativecommons.org/licenses/by-nc-nd/4.0/). Peer-review under responsibility of AMER (Association of Malaysian Environment-Behaviour Researchers), ABRA (Association of Behavioural Researchers on Asians/Africans/Arabians) and CE-Bs (Centre for Environment-Behaviour Studies), Faculty of Architecture, Planning \& Surveying, Universiti Teknologi MARA, Malaysia.

DOI: https://doi.org/10.21834/ebpj.v6iSI4.3028

\subsection{Introduction}

In Malaysia, the current planning mechanisms are recognised as important tools in the housing planning process, especially in urban areas. It is possible for town planning to impose constraints on housing development through the development plan by which the land is identified for future development and development policies on intensity, designs, and land-use zoning. Also, through development control, the local planning authority set procedures to be followed, processing requirements, planning standards, and guidelines, and duration of its activities to preserve, monitor, and protect the environment. The issues concerning the development control process include delay of planning approvals, lack of consistency in decision making, the poor content of the development plans, and lack of workforce resources.

The weaknesses and ineffectiveness of the planning system in the preparation of development plans (Rameli, 2009; 2011; Ahmad, 2011) and its implementation through development control mainly during housing application and approval (Yakob et al., 2012) have significantly given the impact to the housing production process. Thus, the aim is to explore the strategies or plan of actions to ensure the effectiveness of planning activities such as policy formulation, land location, size determination of housing development, and housing application procedures. The planners viewed the current practices of housing planning in the study area as weak and ineffective based on certain highlighted aspects. They postulate that the existence of housing problems in Selangor occurred due to the weaknesses and the ineffectiveness of the housing planning process, starting from the formulation of the policy stage to the planning control stage.

One of the most critical issues is there are loopholes in the formulation of the policy due to several aspects such as market fluctuation, unavailability of data to monitor the implementation of policies (Rameli, 2009; Mohd, 2011; Foo et al., 2014), inadequate computerised systems in the applications submitted and existing housing developments (Chua \& Deguchi, 2008), durations for Local Plan (LP) reviews

eISSN: 2398-4287@ 2021. The Authors. Published for AMER ABRA cE-Bs by e-International Publishing House, Ltd., UK. This is an open access article under the CC BYNC-ND license (http://creativecommons.org/licenses/by-nc-nd/4.0/). Peer-review under responsibility of AMER (Association of Malaysian Environment-Behaviour Researchers), ABRA (Association of Behavioural Researchers on Asians/Africans/Arabians) and CE-Bs (Centre for Environment-Behaviour Studies), Faculty of Architecture, Planning \& Surveying, Universiti Teknologi MARA, Malaysia.

DOI: https://doi.org/10.21834/ebpj.v6iSI4.3028 
(Yakob, 2012), lack of experience among officers (Yakob, 2013; Monkkonen, 2013). Little study on income projections and lack of housing market consideration during feasibility studies (Rameli et al., 2011; Dunse, 2013).

Most planners perceived that consideration of economic factors in determining land location, especially in terms of housing demand, has been given less attention. Consequently, this generates housing zones that do not reflect the actual demand (Jae, 2011; Gurran et al., 2011). They also pointed out errors in the calculation of population projection, which results in surplus and shortages. Other factors of oversupply highlighted by the respondents are poor implementation and enforcement (Othman, 2006), locational disadvantages (Rameli, 2007; Mohd et al., 2009; Lin, Y. \& Meulder, B. 2012), unaffordable price of the houses (Burgress, 2010; Bakhtiyar, 2013), over planning and land expansion.

Furthermore, concerning land size, it was claimed that there is no actual data on the types of houses based on income patterns of people who need housing. Besides, they also pointed out that there are loopholes in planning guidelines for housing development, especially within the provision of community facilities and open space (Maliene et al., 2005; Mohd et al., 2007; Mohit et al., 2010; Ismail et al., 2015). It was claimed that the problems are much related to the size and quantity required for facilities and open space provisions within the housing areas. This is due to the increased land value and limited access to land supply.

In addition to the planning control aspect, most planners perceived that the level of compliance is low for issues of low-cost housing $(\mathrm{LCH})$ policies and housing category, especially for $\mathrm{LCH}$ and medium-low cost housing (MLCH). Among the factors leading to noncompliance is weaknesses in the preparation of the structure plan (SP) and local plan (LP) (Yakob, 2015, Yakob, 2016), not enough understanding of zoning and laws, the prolonged period of plan reviews which lead to out-dated content, lack of integrity among officers and the pressures of development (Osman et al., 2014). Regarding the factor of difficulty during the planning control process, they perceived that waiting time (Ball, 2011) is the most difficult, especially when it comes to water supply requirements in the study area. Political influences have caused difficulty in getting approvals (Ahmad, 2013). They also perceived that in some cases, bribery is encouraged due to the issues of delays.

\subsection{Material and Method}

The study is conducted through a face-to-face expert interview approach with the government planners and planning consultants in Selangor as a sample. To select appropriate respondents, the purposive sampling technique was applied by choosing respondents based on their years of experience of more than ten (10) years and their involvement in the preparation of development plans, housing layout plans, submission, and approval of housing planning applications. A total of fifteen respondents $(n=15)$ was selected and interviewed which includes a State Deputy Director, divisional heads of Federal Town and Country Planning Department $(n=2)$, an employee of Lembaga Perumahan Dan Hartanah Selangor $(n=1)$, and Assistant Directors from local planning authorities (LPAs) ( $n=2)$. They hold professional managerial positions with $\mathrm{J} 48$ and above. The remaining respondents are private town planners holding the positions of Principals of town planning $(n=8)$ and Assistant Principal $(n=1)$ of consultant firms. They are also corporate members of the Malaysian Institute of Planners (MIP). These respondents were identified after analysing the data from the respondent's profile collected during the questionnaire survey. In analysing the data, government planners were coded as G10 to G15 and planning consultants as P1 to P9 (refer figure 1).

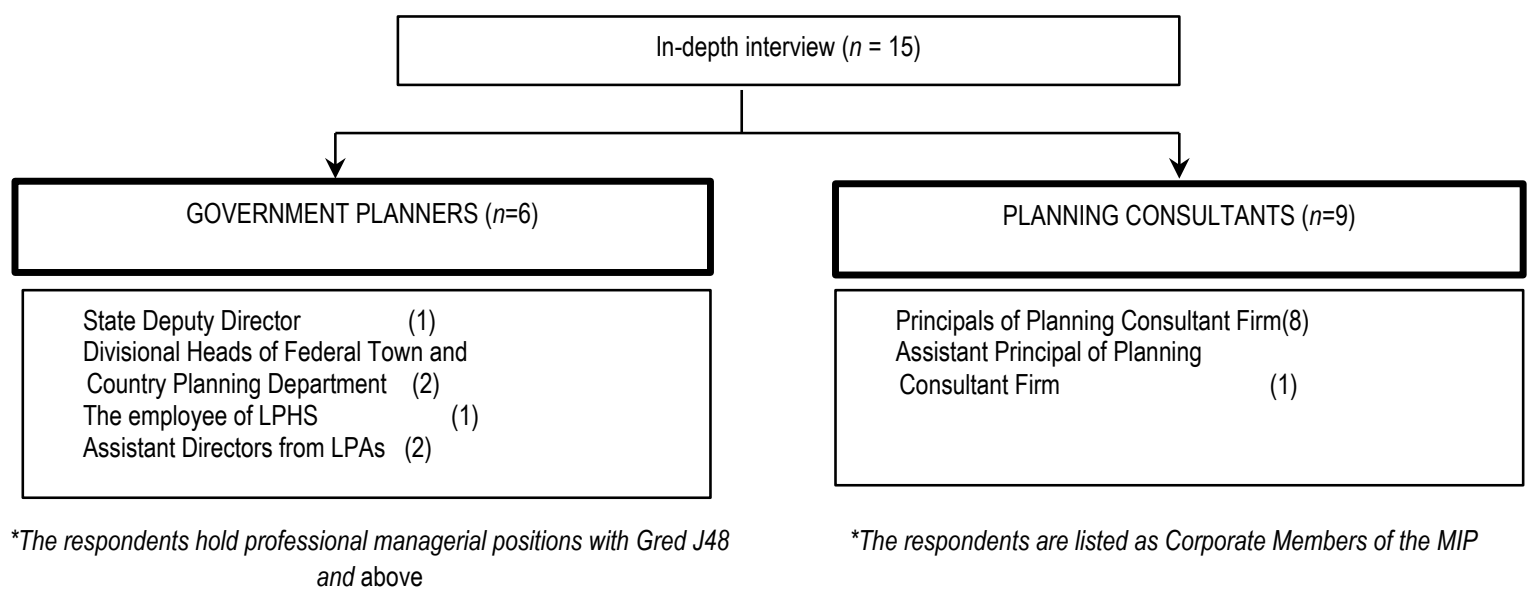

Fig. 1: Category and Total Number of Respondents involves in An In-Depth Interview

The interview session was started for two and a half months, from 10 July to 20 September 2014 . The questions comprised seven (7) main questions that attempted to gain insight on the issues and problems and uncover the reasons behind the current practices of housing planning and control in the study area. Questions highlighted were; 1) loopholes in the policy for housing, 2) advantages and disadvantages of the new policy "Rumah Selangorku," 3) Factor of land location, 4) Factor of land size, 5) Factor of non-compliance with planning requirements, 6) Factor of difficulties during the housing approval process, and 7) Suggestions to improve the housing planning and control system. 
However, this paper only discusses question 7 , which was based on issues and problems raised in questions 1 to 6 . Each session took approximately 60 to 90 minutes, depending on respondents' interest and was video and audio recorded. However, this study has a limitation. During the interviews, the respondents are unable to answer the questions correctly and tendency to elaborate on certain aspects that were out of the scope of the issues. Therefore, in some cases, the researcher had to guide respondents and propose several answers to avoid bias in terms of response accuracy. Also, additional explanations were omitted during the analysis.

Atlas.ti software was used to find deeper meaning and connections within the interview transcripts by mining for themes, similarities and differences (Friese, 2012). All responses were coded as lean coding using an Atlas.ti software. Lean-coding was derived from variables or concepts in the study, namely policy, land location, land size, guidelines, and housing application and approvals as well as recommendations. Each variable was coded into several categories (families) that answer the research questions and their objectives. The transcript files were assigned and imported into a new "Hermeneutic Units" (HU) or a project in the software. The HU editor then shows the content of all data files, and the quotations were coded following suitable coding items derived from the research questions.

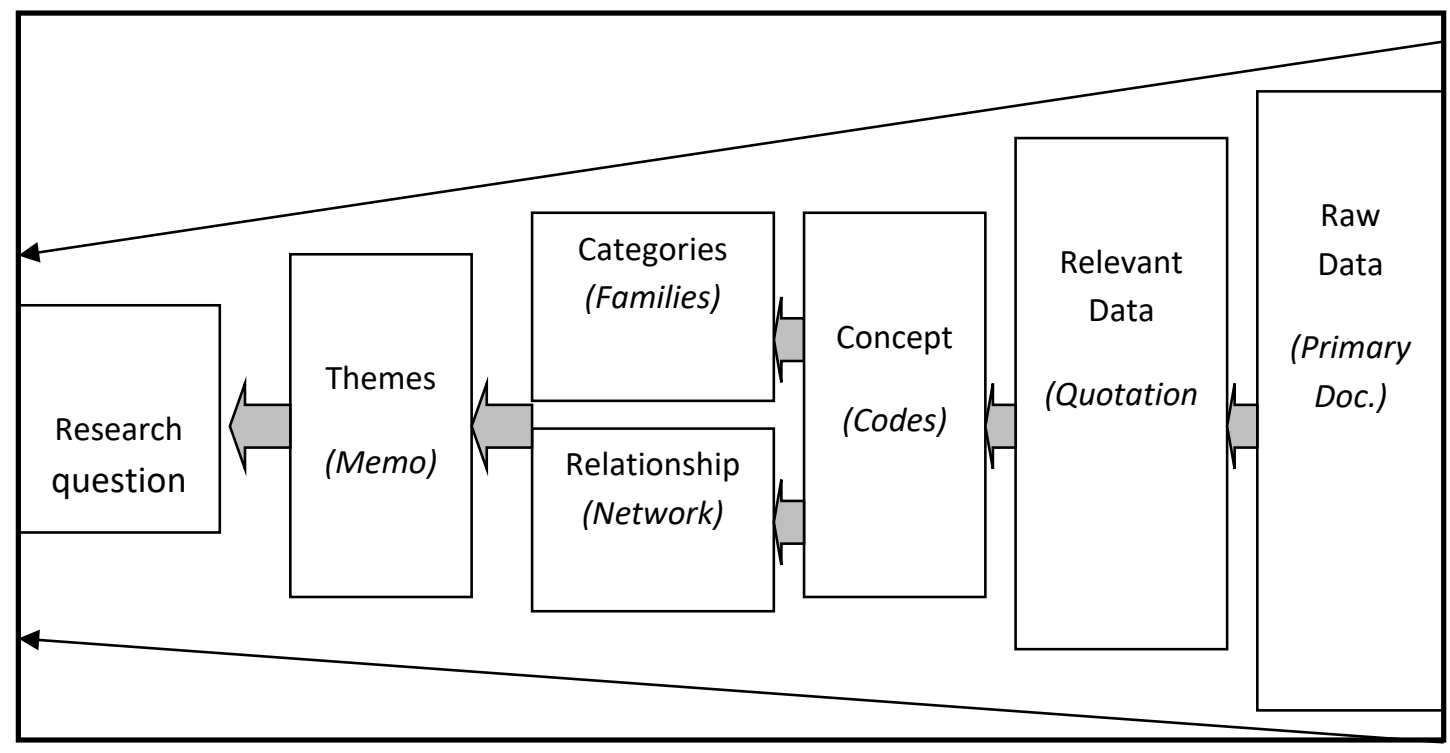

Fig. 2: Flow of data analysis to develop themes related to the research questions (Source: Ducharme, 2014)

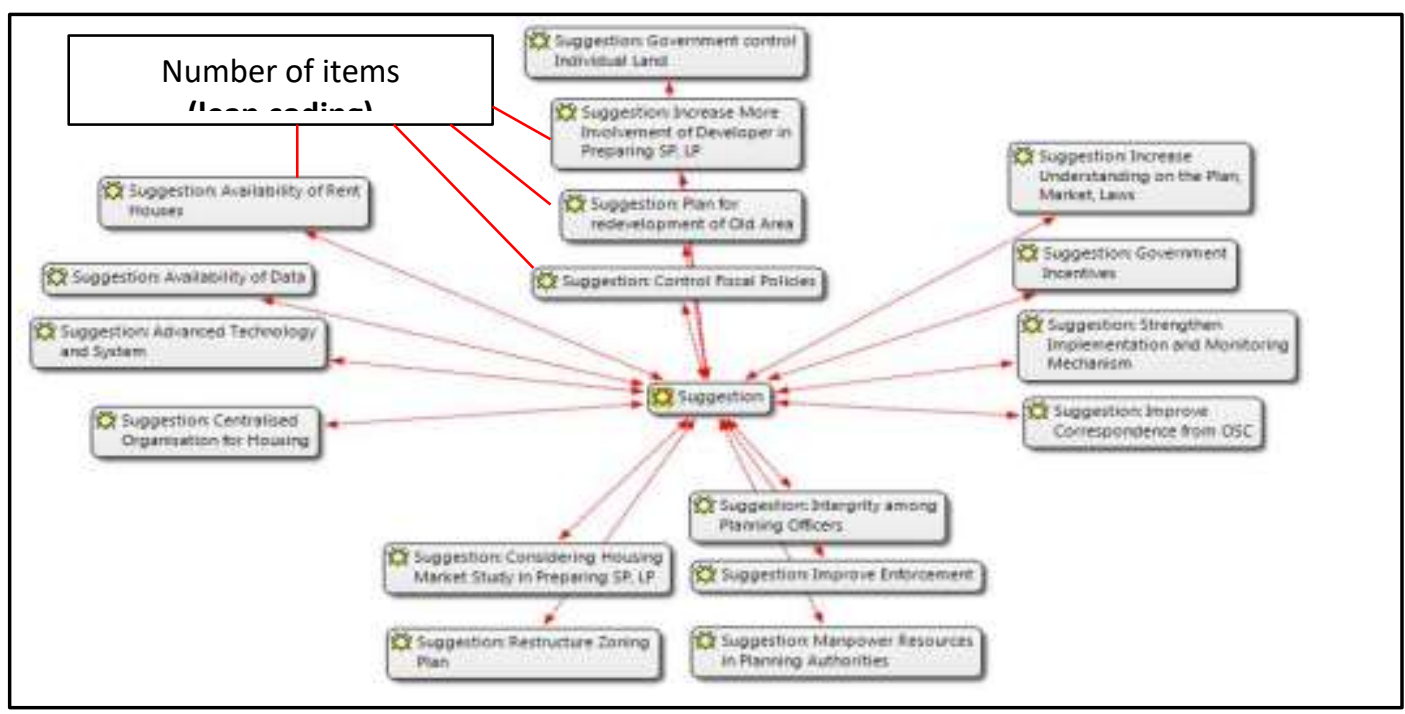

Fig. 3: Network Mapping with 17 items (lean-codes) as output from Atlas.ti software

The number of items for each coding was then identified and categorised from the list of quotations. As output, network mapping (relationships) was used to build theoretical models defined by a set of nodes and links within Atlas.ti. (Figure 3). These nodes can be any number of objects, which are - Quotations.

Meanwhile, links were also used to specify the relationship between two nodes. Figure 2 shows the flow of data to develop the themes leading back to the research questions. The software does not write the report but helps in narrating components by providing visual representations and readily available quotes to be incorporated in the report (Ducharme, 2014). 


\subsection{Result and Discussion}

Based on the result from Atlas.ti, there are seventeen (17) items (based on lean coding), as output included in the network mapping relating to suggestions and recommendations highlighted by government and private planners during the interview survey. However, for a summary of findings in Table 1, two (2) items - considering housing market study \& improve enforcement were combined with SG10 and SG14, respectively. The suggestions refer to the question of "How to streamline and strengthen the planning and control in urban housing development?" Findings indicated that suggestions from respondents fall within two (2) categories; during the preparation stage and the implementation stage. In this case, the implementation stage points towards the roles of the Federal government, State government, and Local Planning Authorities (LPAs) (Table 2). Meanwhile, table 1 is a summary of the result showing that suggestion SG4 "availability of data" and SG10 "increasing understanding of the plan, laws and housing market" are the most important aspects to be considered and improved in housing planning and control activities with 47 percent respondents respectively. The recommendations are expected to help improve and make the process of land use planning activities in urban housing development more effective.

Table 1. The summary result of a suggestion to improve housing planning and control in urban housing development

\begin{tabular}{|c|c|c|c|}
\hline Lean-Coding & Description of suggestions & $\begin{array}{c}\text { Respondent Rate } \\
N=15 \\
(\%) \\
\end{array}$ & Ranking Rate \\
\hline SG1 & More involvement of developers & $1(7)$ & 6 \\
\hline SG2 & Advanced technology and system & $2(13)$ & 5 \\
\hline SG3 & Centralised organisation for housing & $4(27)$ & 3 \\
\hline SG4 & Availability of data & $7(47)$ & 1 \\
\hline SG5 & Restructure zoning plan & $3(20)$ & 4 \\
\hline SG6 & Integrity among planning officers & $3(20)$ & 4 \\
\hline SG7 & Improve correspondence from OSC & $1(7)$ & 6 \\
\hline SG8 & Availability of rent houses & $2(13)$ & 5 \\
\hline SG9 & Government incentives & $2(13)$ & 5 \\
\hline SG10 & Increase understanding of the plan, laws and market & $7(47)$ & 1 \\
\hline SG11 & Plan for the redevelopment of old areas & $1(7)$ & 6 \\
\hline SG12 & Manpower resources in LPAs & $1(7)$ & 6 \\
\hline SG13 & Control fiscal policies & $1(7)$ & 6 \\
\hline SG14 & Improve enforcement and strengthen implementation and monitoring mechanism & $6(40)$ & 2 \\
\hline SG15 & Government controlled individual land & $3(20)$ & 4 \\
\hline
\end{tabular}

Table 2. Results from In-depth Interview to improve the Housing Planning and Control Process

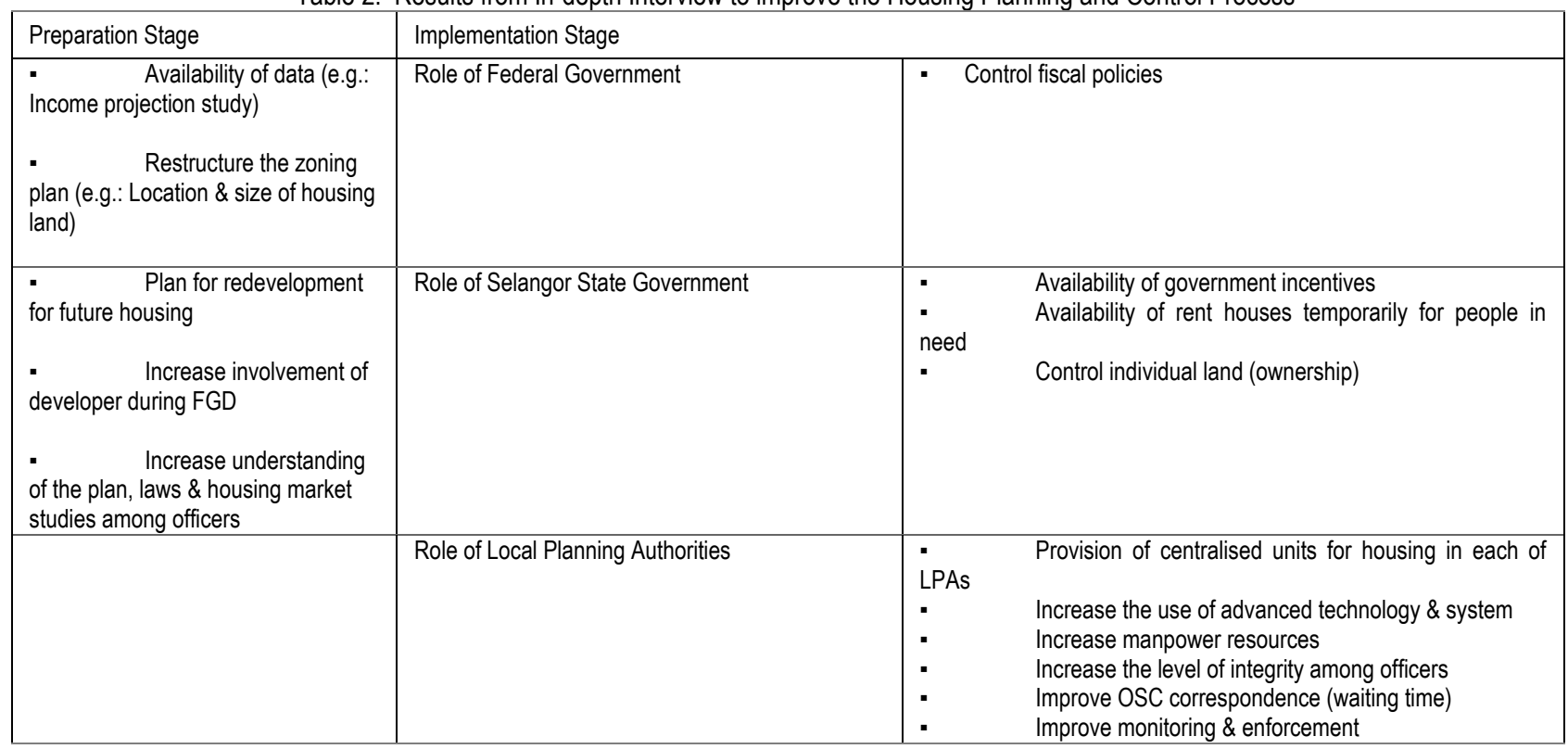

\subsection{Conclusion}

This paper has presented a framework of strategies to ensure the effectiveness of housing planning and control activities through an indepth interview with planners. The analysis indicates housing market study in terms of demand and price of houses should be considered during the preparation of structure plan (SP) and local plan (LP). To portray the actual requirements of future housing in certain areas, housing forecasting is vital, other than the total quantity of housing needs. The analysis also indicates the formulation of specific policies that enable the LPAs to consider the housing market and study on income projections in the process of housing approval are essential 
to be formulated in the SPs. Additionally, the consideration of housing market demands in determining a location for future housing development is very appropriate and rational.

Failure in the distribution of the housing land area, the analysis indicates that there are many contributing factors and justifications. The leading causes are the influence and interference of politicians, lack of income study, poor implementation, zoning not reflecting the actual demand, and zoning not taking into account the amount of land acquired. Concerning non-compliance, there are suggestions highlighted, such as improvement of planning control in terms of enforcement and monitoring mechanisms, increasing the level of knowledge and integrity among those involved in approvals. Furthermore, it was perceived that the problem of waiting time could be improved through the use of advanced technology and system in LPAs. The increase in workforce resources for monitoring implementation will enhance and strengthen enforcement.

This paper's outcomes are expected to guide future researchers in exploring land-use planning activities and urban housing development processes. Furthermore, the weaknesses that were identified, together with the suggestions to improve the process of housing planning and control activities, could be a useful reference for urban planners, LPAs as well as state authorities in planning and controlling housing supply more effectively. However, it should also be noted that this research requires continuous assessment by identifying and ranking the significant factors and explaining the relationship between issues, the contributing factors, or both. The property players not limited to the perspective of town planners as in this paper, such as housing developers, property analysts, local councillors, and house buyers, maybe approached to gain information about the contributing factors.

\section{Acknowledgement}

This research paper is funded by the Ministry of Education, Malaysia and Universiti Teknologi MARA. Also, special thanks to the respective respondents for all their cooperation in participating in this in-depth interview survey.

\section{References}

Ahmad, F., Mohd, I., Maidin, S.L., Zainol, R., \& Mohd Noor, N. 2013. Malaysian Development Plan System: Issues and Problems, One Decade After its Reform (20012011). Journal of Malaysian Institute of Planners, 11:1-20

Bakhtyar, B., Zaharim, A., Sopian, K., \& Moghimi, S. 2013. Housing for Poor People: A Review on Low- Cost Housing Process in Malaysia.WSEAS Transactions on Environment and Development, 9: 126-136.

Ball, M. 2011. Planning Delay and The Responsiveness of English Housing Supply. Urban Studies.48 (2): 349 -362.

Burgess, G,.Monk, S. \& Whitehead, C. 2010. How Can The Planning System Deliver More Housing?. Joseph Rowntree Foundation. 1-8.

Chua, R.S., \& Deguchi, A. 2008. Implementation Issues on Planning Control according to the Provision of Town and Country Planning Act 1976 in Malaysia. Journal of Architecture and Urban Design, 14:47-58

Dunse, N., Thanos, S. \& Bramley, G. 2013. Planning Policy, Housing Density and Consumer Preferences. Journal of Property Research.30 (3):221 -238.

Durcharme, D.R. 2014. Factors that Influence the Use of Qualitative Methods by Institutional Researchers. PhD Thesis. Johnson \& Wales University.

Foo, L. H.R., \& Wong, C. 2014. Planning for Housing Development in Malaysia: Developers' Response to the Regulatory Policy Framework. International Planning Studies. 19 (2):192- 209.

Friese, S. 2012. Qualitative Data Analysis using Atlas.ti. SAGE Publication. United Kingdom

Gurran, N., Gilbert, C. \& Phibbs, P. 2013. Planning and the Housing Market: Measuring Regulatory Difference and Implications for Explaining Supply and Affordability Trends. $7^{\text {th }}$ Australasian Housing Researchers' Conference. $6^{\text {th }}-8^{\text {th }}$ February 2013.

Gurran, N., \& Whitehead, C. 2011. Planning and Affordable Housing in Australia and the UK: A Comparative Perspective. Housing Studies. 26 (7-8):1193- 1214.

Ismail, W \& Said, I. 2015. Integrating the Community in Urban Design and Planning of Public Spaces: A Review in Malaysian Cities. Procedia-Social and Behavioural Sciences, 168:357-364

Jae, H.K. 2011. Linking Land Use Planning and Regulation to Economic Development: A Literature Review. Journal of Planning Literature. 26 (1): $35-47$.

Lin, Y. \& Meulder, B. 2012. A Conceptual Framework for the Strategic Urban Project Approach for the Sustainable Development of "Villages in the City" in Guangzhou, Habitat International. 3: 380-387.

Maliene, V. \& Malys, N. 2009. High- Quality Housing- A Key Issue in Delivering Sustainable Communities. Building and Environment Journal. 44 (2): $426-430$.

Mohd, I, Ahmad, F. \& Aziz, WA. 2009. Exploiting Town Planning Factors In Land Development: Case Study Of Urban Housing In Kuala Lumpur, Malaysia. Journal of Facilities Management. 7 (4): $307-318$.

Mohd, I, Arby, E. \& Ramly, A. 2007. Urban Housing Development: Town Planning Issues. Journal of Malaysian Institute of Planners, 43-59.

Mohd, T. \& Alias, G. 2011. The Role of Housing Planning Practices In Contributing To Housing Oversupply. World Academy of Science, Engineering and Technology. 59: 767-775. 
Mohit, M., Ibrahim, M. \& Rashid, Y.R. 2010. Assessment of Residential Satisfaction in Newly Designed Public Low-Cost Housing in Kuala Lumpur, Malaysia. Habitat International. 34 (1): 18-27.

Monkkonen, P. 2013. Urban Land Use Regulations And Housing Markets In Developing Countries: Evidence From Indonesia On The Importance Of Enforcement. Land Use Policy Journal. 34: 255-264

Osman, M, Bachok, S, Bakri, N.I, \& Harun, N. 2014. Government Delivery System: Effectiveness of Local Authorities in Perak, Malaysia. Procedia Social and Behavioural Sciences. 153: 452-462

Othman, A. 2006. Developer's Strategies in Dealing with Planning Control: Its Impact On The Urban Housing Development. Malaysian Journal of Real Estate. 1(2): 7-15.

Rameli. A. 2007. Application Of Method Of Content Analysis And Perception Survey In Evaluating The Effectiveness Of Planning System In Managing Housing Supply. Proceedings of the $2^{\text {nd }}$ Post Graduate Seminar on Research of Built Environment 2007. March 6. Faculty of Built Environment. Universiti Teknologi Malaysia.

Rameli. A. 2009. Land Use Planning System and Housing Development. PhD Thesis. UTM, Malaysia

Rameli, A. \& Aman, R. 2011. Ineffectiveness of Planning Control and Its Implications to Housing Oversupply. Journal of Civil Engineering and Architecture. 1-15

Yakob, H., Yusof, F., \& Hamdan, H. 2012. Land Use Regulations towards Sustainable Urban Housing: Klang Valley Conurbation. Procedia Social and Behavioural Sciences, 68: 578-589

Yakob, H., Yusof, F., \& Hamdan, H. 2013. Sustainable Urban Housing Development through Planning Mechanism: Issues and Challenges. Asia Pacific Network for Housing Research (APNHR) Proceedings

Yakob, H., Yusof, F., \& Hamdan, H. 2015. Stakeholders' Perception on the Effectiveness of Housing Planning And Control In Urban Areas: A Preliminary Survey. Procedia Social and Behavioural Sciences, 168: 289-301.

Yakob, H., Yusof, F., \& Hamdan, H. 2015. A Quadrant Analysis on the Effectiveness of Planning And Control In Urban Housing Development in Selangor.E-BPJ, 1 (1), June 2016 168: 251-259.

Yakob, H., Yusof, F., \& Hamdan, H. 2016. Measuring the Effectiveness of Planning and Control. Asian Journal of Behavioural Studies, AjBeS 1 (4), Nov/ Dec: 11-23.

Yakob, H. 2017. The Effectiveness of Land Use Planning in Urban Housing Developments in Selangor. PhD Thesis. Universiti Teknologi MARA 